Revue d'histoire de l'Amérique française

REYUE D.HISTOIRE DE L'AMÉRIQUE FRANÇAISE

PIZZORUSSO, Giovanni, Roma nei Caraibi. L'organizzazione delle missioni cattoliche nelle Antille e in Guyana (1635-1675) (Rome, École française de Rome, 1995), 366 p.

\title{
Dominique Deslandres
}

Volume 51, numéro 3, hiver 1998

URI : https://id.erudit.org/iderudit/005394ar

DOI : https://doi.org/10.7202/005394ar

Aller au sommaire du numéro

Éditeur(s)

Institut d'histoire de l'Amérique française

\section{ISSN}

0035-2357 (imprimé)

1492-1383 (numérique)

Découvrir la revue

Citer ce compte rendu

Deslandres, D. (1998). Compte rendu de [PIZZORUSSO, Giovanni, Roma nei Caraibi. L'organizzazione delle missioni cattoliche nelle Antille e in Guyana (1635-1675) (Rome, École française de Rome, 1995), 366 p.] Revue d'histoire de l'Amérique française, 51(3), 463-464. https://doi.org/10.7202/005394ar d'utilisation que vous pouvez consulter en ligne.

https://apropos.erudit.org/fr/usagers/politique-dutilisation/ 


\section{NOTE BIBLIOGRAPHIQUE}

PIZZORUSSO, Giovanni, Roma nei Caraibi. L'organizzazione delle missioni cattoliche nelle Antille e in Guyana (1635-1675) (Rome, École française de Rome, 1995), 366 p.

Voici un ouvrage très érudit, très clair et très attendu qui vient combler bien des vides de l'historiographie du colonialisme et de la conversion au $\mathrm{XVII}^{\mathrm{e}}$ siècle. Roma nei Caraibi de Giovanni Pizzorusso renouvelle en profondeur l'histoire des missions et des liens entretenus par le Saint Siège avec le Nouveau Monde. Il faut dire que l'histoire religieuse des Antilles et de la Guyanne, qui est au cœur de cette étude, n'a guère retenu l'attention des historiens. Souvent datés, souvent parcellaires et événementiels, les travaux sur ce sujet n'offrent pas la vue d'ensemble qui fait la force du livre de Pizzorusso; ils traitent à part l'histoire des îles, les déconnectant de l'histoire de la NouvelleFrance; ils évoquent trop rapidement l'établissement des structures ecclésiastiques locales, l'implantation des ordres et leurs rivalités, oubliant l'organisation internationale que cherche alors à être le Saint Siège; ils donnent des contours flous à la difficile coexistence ethnique (Européens, Amérindiens et Africains de la déportation) et religieuse (catholiques, protestants, juifs et «païens»). Autant de lacunes que comble l'ouvrage de Pizzorusso.

Maniant avec une grande dextérité les archives romaines - principalement celles de la Propaganda Fide, celles du Vatican, celles des ordres religieux —, l'auteur apporte un complément documentaire essentiel alors que, jusqu'à présent, les historiens se sont principalement fondés sur les archives françaises et anglaises. Quatre grands chapitres analysent les rapports de l'Église coloniale avec les colons, les missions auprès des Amérindiens et des esclaves noirs, la répartition de ces missions entre les divers ordres convertisseurs ainsi que la tentative centralisatrice romaine qu'a été la création de la Congrégation de Propaganda Fide. Ainsi en replaçant l'histoire complexe des Antilles dans l'histoire globale de l'époque, en mettant au jour les dynamiques qui lient la métropole, Rome et les colonies insulaires, Pizzorusso redonne aux îles l'importance qu'elles avaient aux yeux des Européens du XVII ${ }^{\mathrm{e}}$ siècle. Au bout du compte, beaucoup plus que le froid Canada, les îles ont fait rêver tout autant les missionnaires, les politiques et les commerçants. C'est un des nombreux mérites de Roma nei Caraibi de nous le rappeler. 